\title{
Editorial
}

\section{Asthma prevalence \& risk factor in children: Indian Scenario}

\section{Gedam DS}

Dr D Sharad Gedam, Professor of paediatrics, L N Medical college, Bhopal, India \& Editor- in- chief, IJMRR

Address for correspondence: Dr D Sharad Gedam, Email: editor.ijmrr@gmail.com

\begin{abstract}
Various risk factors play a role in triggering allergic diseases among low-income households in developing countries. Indoor smoking, pets, overcrowding are some of the known factors for asthma.
\end{abstract}

Key words: Asthma, risk factor, low income countries.

\section{Introduction}

Asthma is chronic respiratory disorder characterized by hyper responsiveness of airway system by various stimuli. There is a complex interaction between various stimuli, mediators \& airways. Asthma is characterized by following sysmptoms.

1. Recurrent episode of breathlessness with chest tightness, wheeze and cough.

2. Airflow obstruction characterized by decrease air entry on auscultation or by spirometry examination.

3. Hyper responsiveness to various inhaled or non inhaled stimuli.

\section{Prevalance}

Data related with prevalence in India is limited. It varies from 2.3 to $11.6 \%$ in various studies conducted in India [1-8]. ISAAC study conducted in India in 14 centres has shown prevalence of $3.7 \% \& 4.5 \%$ in $6-7$ years \& $14-15$ years population [9].

National Family Health Survey-3 showed that the prevalence of bronchial asthma among school children of the age group 15-19 years in India is as little as $0.9 \%$, whereas other studies showed varied results ranging from $1.9 \%$ to $16.6 \%$ in different age groups [10].

Although very less is known about contribution of each risk factor associated with asthma such as family history, type of fuel used, pet animals, indoor air pollution, birth order, smoking among family members, will help in adopting appropriate preventive strategies. There is statistically significance association between family history, smoking in any of the family member \& absence of smoke outlet at homes [11].

Gaffin JM et al revealed that early life exposure to allergens (house dust mite (HDM), furred pets, cockroach, rodent and mold), air pollution (nitrogen dioxide $\left(\mathrm{NO}_{2}\right)$, ozone $\left(\mathrm{O}_{3}\right)$, volatile organic compounds (VOCs), and particulate matter (PM)) and viral respiratory tract infections (Respiratory syncytial virus (RSV) and human rhinovirus (hRV)) has been implicated in the development of asthma in high risk children [12].

The presence of mold and water leakage in houses were the most important risk factors with indoor smoking for asthma [13]

George et al has done a study to determine the prevalence of bronchial asthma among children of $5-15$ years and its environmental determinants in urban slum. In her study she has not found association between prevalence of asthma and presence of separate kitchen.

Although presence of pets $(\mathrm{OR}=2.70)$ and inadequate ventilation $(\mathrm{OR}=2.71)$ were independently associated with bronchial asthma in children of school going age. Multicentre study should be planned to identify modifiable risk factor India [12].

\section{References}

1. Chhabra SK, Gupta CK, Rajpal S, Chhabra P. Prevelance of asthma in school children in Delhi. J Asthma 1988;0:291-96. 


\section{Editorial}

2. Pal R, Dahal S, Pal S. Prevalence of bronchial asthma in Indian children. Indian J Community Med. 2009;34:310-6.

3. Jain A, Vinod Bhat H, Acharya D. Prevalence of bronchial asthma in rural Indian children: A cross sectional study from South India. Indian J Pediatr. 2010;77:31-5.

4. Chakravarthy S, Singh RB, Swaminathan S, Venkatesan P. Prevalence of asthma in urban and rural children in Tamil Nadu. Natl Med J India. 2002;15:2603 .

5. Narayana PP, Prasanna MP, Narahari SR, Guruprasad AM. Prevalence of asthma in school children in rural India. Ann Thorac Med. 2010;5:118-9.

6. Dhabadi BB, Athavale A, Meundi A, Rekha R, Suruliraman M, Shreeranga A, et al. Prevalence of asthma and associated factors among schoolchildren in rural South India. Int J Tuberc Lung Dis. 2012;16:1205.

7. Behl RK, Kashyap S, Sarkar M. Prevalence of bronchial asthma in school children of 6-13 years of age in Shimla city. Indian $J$ Chest Dis Allied Sci. 2010;52:145-8.

8. Sharma BS, Kumar MG, Chandel R. Prevalence of asthma in urban school children in Jaipur, Rajasthan. Indian Pediatr. 2012;49:835-6.
9. Asher MI, Keil U, Anderson HR, Beasley R, Crane J, Martinez F, et al. International Study of Asthma and Allergies in Childhood (ISAAC): Rationale and methods. Eur Respir J.1995;8:483-91.

10. National family health survey. Available online on http://www.rchiips.org/nfhs/urban_health_report_for_w ebsite_18sep09.pdf cited on 20/10/2014.

11. Kumar GS, Roy G, Subitha L, Sahu SK. Prevalence of bronchial asthma and its associated factors among school children in urban Puducherry, India. J Nat Sci Biol Med. 2014 Jan;5(1):59-62. doi: 10.4103/09769668.127289

12. Gaffin $\mathrm{JM}^{1}$, Kanchongkittiphon $\mathrm{W}^{2}$, Phipatanakul W. Reprint of: Perinatal and early childhood environmental factors influencing

allergic asthmaimmunopathogenesis. Int Immunopharmacol. 2014 Oct 7. pii: S15675769(14)00380-4. doi: 10.1016/j.intimp.2014.09.028.

13. Seo S, Kim D, Paul C, Yoo Y, Choung JT. Exploring Household-level Risk Factors for Self-reported Prevalence of Allergic Diseases Among Low-income Households in Seoul, Korea. Allergy Asthma Immunol Res. 2014 Sep;6(5):421-7. doi: 10.4168/aair.2014.6.5.421

14. George CE, Chopra H, Garg SK, Bano T, Jain S, Kumar A. Environmental Correlates of Bronchial Asthma in Children in a Slum of Meerut - A CrossSectional Study. Int J Med Res Rev 2014;2(5):469- 473.

\section{How to cite this article?}

Gedam DS. Asthma prevalence \& risk factor in children: Indian Scenario. Int J Med Res Rev 2014;2(5):407-408. doi:10.17511/ijmrr.2014.i05.01 